is evil, all is well; but if he should inspire respect, his influence would be considered sectarian and he would be subject to dismissal. The alternative is to conceal, hide, or deny his religious affiliations-but that is not the religious liberty guaranteed by the state and federal constitutions.

Applying the clear and present danger test to determine whether or not the evil that the state has a right to prevent is sufficiently grave to justify the impairment of religious liberty, it is clear that the "evil" which the courts and legislatures have sought to suppress is a "respect" for a particular religion. In order to suppress this "evil," religious freedom, one of the most important of our fundamental liberties that occupy a preferred position in the hierarchy of our constitutional values, is impaired. This respect which accrues to a religious belief because some public school teachers live their faith is, under this test, the "substantial evil" that is supposed to constitute a certain and imminent peril to the foundations of our society.

\title{
RELIGIOUS GARB IN THE PUBLIC SCHOOLS A STUDY IN CONFLICTING LIBERTIES
}

American society is protected on both a national and state level by constitutional guarantees of freedom of religion. ${ }^{1}$ Such guarantees imply that religious freedom

must be so exercised by him to whom it is given as not to infringe upon the equally sacred right of his neighbor to differ with him. ${ }^{2}$

\section{Application of this principle dictates that the states must}

maintain the common school system free from sectarian influence or control and ... preserve the equal right of every citizen to have his children educated in these schools of the people without being subjected to the slightest sectarian leading upon the part of their teachers. ${ }^{3}$

\footnotetext{
${ }^{1}$ Two federal constitutional provisions apply to religious liberty. "[N]o religious test shall ever be required as a qualification to any office or public trust under the United States." U.S. Const. Art. 6, $\$ 3$. "Congress shall make no law respecting an establishment of religion, or prohibiting the free exercise thereof. . . ." U.S. Const. Amend. 1. The latter principle has also been held applicable to state action by the Fourteenth Amendment. Everson v. Board of Education, 330 U.S. 1 (1947); Zellers v. Huff, 55 N.M. 501, 236 P. 2d 949 (1951). The state constitutions generally follow the federal constitutional provisions in this area.

"All states provide religious liberty to a greater or less degree. Most states prohibit the use of religious tests as qualifications for holding public office, altho in several, atheists are excluded. Compulsory attendance at places of public worship is universally unconstitutional. ... [J] udicial interpretation has usually gone to the spirit of the language and the courts are unanimous in holding that no union of church and state is possible under our state constitutions." 24 Research Bulletin of the National Education Association 13 (1946).

${ }^{2}$ Knowlton v. Baumhover, 182 Iowa 691, 703, 166 N.W. 202, 206 (1918).

${ }^{8}$ Ibid., at $719,211$.
} 
A most frequent controversy in this area occurs when teachers clothed in religious garb are employed in the public school. ${ }^{4}$ The argument in favor of permitting such garb generally proceeds on two grounds: First, that it is protected as an incident of the religious freedom of the wearer; and secondly, that in any event, the garb has no effect on the public school pupils. ${ }^{5}$ The latter ground is essentially an attempt to negate the possibility that religious garb may violate the religious liberty of the student. This comment will examine how the courts and legislatures have dealt with this problem and will consider, in the context of the principle of separation of church and state, the possible effects of allowing religious garb in the public school.

\section{I}

All states guarantee to the individual freedom to worship according to the dictates of his conscience. ${ }^{6}$ The further provision that no one shall be compelled to support, by taxes or otherwise, any sectarian religious instruction ${ }^{7}$ clearly prevents governmental support for verbal sectarian teaching. The more difficult problem is presented when, without any doctrinal religious teaching, the student in the public school is exposed to religious symbolism such as that which flows from religious garb.

The wearing of religious habiliment by teachers while instructing in the public schools has often incurred public opposition. ${ }^{8}$ This opposition, as the cases indicate, has been directed primarily at the Roman Catholic Church, ${ }^{9}$ since typically clerics of other religions do not wear distinctive garb. ${ }^{10}$

4 Consult State Authorities Sweat over Teaching-Nun Issue, 6 Church and State, No. 8, at 1 (Sept., 1953).

'Consult Blum, Religious Liberty and the Religious Garb, p. 875 supra.

- See note 1 supra.

${ }^{7}$ Almost all states include a constitutional provision prohibiting the use of tax revenues for sectarian purposes. "There is, in fact, considerable variation from state to state, not only in the language of these provisions, but also in their scope. Sometimes the term "public money" is used, indicating that any revenue is restricted, regardless of source. In other states, the expression used suggests that all state money is limited but not revenue collected locally." 24 Research Bulletin of the National Education Association 11 (1946).

${ }^{8}$ Consult 2 Stokes, Church and State in the United States 662-71 (1950).

- To date, nine cases have highlighted the garb issue; all have involved Roman Catholic teachers: Hysong v. School Dist. of Gallitzin Borough, 164 Pa. 629, 30 Atl. 482 (1894); O'Connor v. Hendrick, 184 N.Y. 421, 77 N.E. 612 (1906) ; Commonwealth v. Herr, 229 Pa. 132, 78 Atl. 68 (1910) ; Knowlton v. Baumhover, 182 Iowa 691, 166 N.W. 202 (1918); Gerhardt v. Heid, 66 N.D. 444, 267 N.W. 127 (1936); State ex rel. Johnson v. Boyd, 217 Ind. 348, 28 N.E. 2 d 256 (1940); City of New Haven v. Town of Torrington, 132 Conn. 194, 43 A. 2d 455 (1945); Zellers v. Fuff, 55 N.M. 501, 236 P. 2d 949 (1951); Berghorn v. Reorganized School Dist. No. 8, - Mo. —, 260 S.W. 2d 573 (1953).

For a commentary on the federal government's experience with religiously garbed teachers in the Indian schools, see Stokes, op. cit. supra note 8, at 285-92.

10 "Speaking generally, there is no more valid objection to an eligible nun being employed as a teacher than to a Protestant minister. They stand on the same footing from 
If no statute is involved, the courts must determine whether religious garb violates a state constitutional mandate against sectarian influence in public schools. ${ }^{11}$ Because the state constitutions vary in their language, the courts have declared their tests in such terms as sectarian "teaching,"12 "control,"13 and "schooling."14 These tests appear to express the varying degrees of "sectarian influence" which the courts consider violative of their particular constitution.

In none of these cases has garb been the sole religious influence alleged. ${ }^{15}$ Where garb is one of a number of nonverbal religious influences which create a sectarian atmosphere, the courts aggregate the influences to determine illegality. ${ }^{16}$ If the illegal degree is reached, all contributing influences are enjoined. ${ }^{17}$ The courts have held, however, that the wearing of religious garb by public-school teachers, absent other factors, does not violate any express constitutional provisions. ${ }^{18}$

a public-school standpoint, but Protestant ministers engaged as teachers seldom wear a distinctive habit. . ." Stokes, op. cit. supra note 8, at 590. A factor in initiating these suits may be the fear of the Roman Catholic Church as a potential threat to religious freedom. Consult Katz, Freedom of Religion and State Neutrality, 20 U. of Chi. L. Rev. 426, 436-37 (1953).

${ }^{11}$ E.g., Gerhardt v. Heid, 66 N.D. 444, 267 N.W. 127 (1936).

12 E.g., State ex rel. Johnson v. Boyd, 217 Ind. 348, 28 N.E. 2d 256 (1940).

${ }^{13}$ E.g., O'Connor v. Hendrick, 184 N.Y. 421, 77 N.E. 612 (1906).

${ }^{14}$ E.g., Gerhardt v. Heid, 66 N.D. 444, 267 N.W. 127 (1936).

${ }^{15}$ Typically, the complaints involve a number of additional influences. Among those cited are: prayers beginning or ending class, Knowlton v. Baumhover, 182 Iowa 691, 166 N.W. 202 (1918); use of religious names, Hysong v. School Dist. of Gallitzin Borough, $164 \mathrm{~Pa} .629,30$ Atl. 482 (1894); use of church buildings and proximity to religious activity, Berghorn v. Reorganized School Dist. No. 8, - Mo. - 260 S.W. 2d 573 (1953); other symbols in the classroom such as holy water fonts, crucifixes, and religious pictures, State ex rel. Johnson v. Boyd, 217 Ind. 348, 28 N.E. 2d 256 (1940); inconveniences suffered by those not participating in religious activity, such as early arrival or late departure by bus to accommodate religious services, Zellers v. Huff, 55 N.M. 501, 236 P. 2d 949 (1951).

${ }^{16}$ Knowlton v. Baumhover, 182 Iowa 691, 166 N.W. 202 (1918) ; Berghorn v. Reorganized School Dist. No. 8, - Mo. —, 260 S.W. 2d 573 (1953). But cf. State ex rel. Johnson v. Boyd, 217 Ind. 348, 28 N.E. 2d 256 (1940).

${ }^{17}$ E.g., Berghorn v. Reorganized School Dist. No. 8, - Mo. —, 260 S.W. 2d 573 (1953).

${ }^{18}$ Hysong v. School Dist. of Gallitzin Borough, 164 Pa. 629, 30 Atl. 482 (1894); City of New Haven v. Town of Torrington, 132 Conn. 194, 43 A. 2d 455 (1945); Gerhardt v. Heid, 66 N.D. 444, 267 N.W. 127 (1936); State ex rel. Johnson v. Boyd, 217 Ind. 348, 28 N.E. 2 d 256 (1940).

It should be noted, however, that some courts have indicated through dicta that the wearing of garb would violate constitutional rights. For example, in Zellers v. Huff, 55 N.M. 501, 525, 236 P. 2d 949, 964 (1951), though the court was faced with a multitude of sectarian influences, it said: "Not only does the wearing of religious garb and insignia have a propagandizing effect for the church, but by its very nature it introduced sectarian religion into the school." The court also implied that the wearing of religious garb and insignia "violates the First Amendment to the Constitution of the United States as 
On the other hand, statutes or administrative regulations banning religious garb for public-school teachers during the school session (often imposed following decisions holding the wearing of such garb constitutional) ${ }^{19}$ have consistently been upheld..$^{20}$ The question is whether the regulation or statute is reasonable in the light of the state constitution, laws and policy. ${ }^{21}$ The statutes are presumptively constitutional and supporting policy has been found in the concept of separation of church and state. ${ }^{22}$

The argument directed against these statutes is the claim that the wearer's "religious liberty" has been curtailed. "Religious liberty," however, has legal meaning only insofar as it is derived from the various constitutional guarantees. The particular guarantee usually relied upon is the provision forbidding religious test or qualification for office. The courts have held that these statutes do not prohibit religious partisans from teaching because the statutes are

directed against acts, not beliefs, and only against acts of the teacher whilst engaged in the performance of his or her duties as such teacher. It is true the acts

made applicable to the states by the Fourteenth Amendment to the Constitution of the United States." Ibid., at 513, 956.

${ }^{19}$ In a survey reported in 1946, the following was related: "In addition to the halfdozen states where there is a law forbidding public-school teachers to wear religious garb, there are a few others where this practice is forbidden by the state department. In still others there is no such practice even tho there is no law or ruling against it. On the other hand, twelve states reported a certain amount of practice. When the law is silent, there were three types of comments made by state superintendents in their reports on this question: many said there was no legislation or ruling in point, and employment of public-school teachers wearing religious garb was a matter within local option; a few said that altho the law was silent, the practice was not generally followed; and three others said that there was at least one local instance of practice, and that it had not been challenged nor forbidden." 24 Research Bulletin of the National Education Association 34 (1946). In reply to a questionnaire as to whether teachers wearing religious garb were employed in the public schools, thirty-eight states reported: sixteen answered affirmatively; twenty-two answered negatively. Ibid., at 36 . Consult Stokes, op. cit. supra note 8, at 590,662 .

In O'Connor v. Hendrick, 184 N.Y. 421, 77 N.E. 612 (1906), the court upheld a superintendent's regulation excluding religious garb from the public schools. The New York constitution at that time prohibited use of public money, funds or credit in aid or maintenance of schools "under control or direction of any religious denomination, or in which any denominational tenet or doctrine is taught." While conceding that the influence of the garb might not amount to "teaching," the court stated that the state constitution expressed "the plainest possible declaration of the public policy of the state as opposed to the prevalence of sectarian influences in the public school." (Emphasis supplied.) Ibid., at 428,614 .

so Commonwealth v. Herr, 229 Pa. 132, 78 Atl. 68 (1910); O'Connor v. Hendrick, 184 N.Y. 421,77 N.E. 612 (1906).

${ }^{21}$ O'Connor v. Hendrick, 184 N.Y. 421, 77 N.E. 612 (1906).

2 "The system of common school education in this commonwealth is the creature of the state, and its perpetuity and freedom from sectarian control are guaranteed by express constitutional provisions. Subject to these, the power to support and maintain an efficient system of public schools, wherein all the children of the commonwealth above the age of six years may be educated, is vested in the Legislature." Commonwealth v. Herr, 229 Pa. 132, 145, 78 Atl. 68, 73 (1910). 
prohibited are those which may indicate, and indeed may be dictated by, the religious sentiments of the teacher. ... Indeed it is impossible to see how civil government could exist, if the dictates of the individual conscience were in every instance where they came in conflict with the law of the land the paramount rule of action. ${ }^{23}$

Furthermore, the religious liberty of one person may not be used to limit the freedom of another. The wearer of religious garb therefore has no greater right to wear garb which may effuse a sectarian influence than the right of the student to be free from such influence. ${ }^{24}$

\section{II}

Even in those cases which hold that the state constitution is not violated by the teachers' wearing religious habit, the courts recognize that the garb has some sectarian influence. At the minimum, the courts concede that

the dress and crucifix impart at once knowledge to the pupils of the religious belief and society membership of the wearer. ${ }^{25}$

Garb may be more objectionable than the crucifix or other personal religious effects since it is more conspicuous and serves as a constant reminder of the teacher's religious affiliation. ${ }^{26}$ Also, the religious habit proclaims the teacher's separation from the secular world, providing a symbol of mystery for the student. ${ }^{27}$ The garb is likely to provoke questions, giving the teacher an opportunity to explain the tenets of the religion.

${ }^{2}$ Ibid., at $140-41,71$. Even when the action is the practice of a religious belief, it may be prohibited. In Reynolds v. United States, 98 U.S. 145 (1878), Chief Justice Waite refused to allow a religious belief as a defense against a polygamy prosecution. "Laws are made for the government of actions, and while they cannot interfere with mere religious beliefs and opinions, they may with practices." Tbid., at 166.

2s "The right of the individual to clothe himself in whatever garb his taste, his inclination, the tenets of his sect, or even his religious sentiments may dictate is no more absolute than his right to give utterance to his sentiments religious or otherwise." Commonwealth v. Herr, $229 \mathrm{~Pa}$. 132, 143-44, 78 Atl. 68, 72 (1910).

${ }^{25}$ Hysong v. School Dist. of Gallitzin Borough, 164 Pa. 629, 657, 30 Atl. 482, 484 (1894). The court goes on to say: "The religious belief of teachers and all others is generally well known to the neighborhood and to pupils, even if not made noticeable in the dress, for that belief is not secret, but is publicly professed. . . . The religion of the teacher being known, a pure unselfish life, exhibiting itself in tenderness to the young, and helpfulness for the suffering necessarily tends to promote the religion of the man or woman who lives it."

${ }^{20}$ Knowlton v. Baumhover, 182 Iowa 691, 716-17, 166 N.W. 202, 210 (1918).

${ }^{27}$ Williams, J., dissenting in Hysong v. School Dist. of Gallitzin Borough, $164 \mathrm{~Pa}$. 629, 659,30 Atl. 482, 485 (1894). Speaking of the religiously garbed teachers, Judge Williams stated: "Wherever they go, this garb proclaims their church, their order, and their separation from the secular world, as plainly as a herald could do if they were constantly attended by such person." This dissent has been cited with approval in O'Connor v. Hendrick, 184 N.Y. 421, 429, 77 N.E. 612, 614 (1906); Knowlton v. Baumhover, 182 Iowa 691, 714, 166 N.W. 202, 210 (1918) ; Zellers v. Huff, 55 N.M. 501, 524, 236 P. 2d 949, 964 (1951). 
One of the purposes of wearing a uniform ecclesiastical robe is to symbolize to the public the tradition and way of life exemplified by the religious. As was indicated in West Virginia State Board of Education v. Barnette ${ }^{28}$ (involving flag saluting in the schools):

Symbolism is a primitive but effective way of communicating ideas. The use of an emblem ... to symbolize some system, idea, institution or personality is a short cut from mind to mind. Causes and nations, political parties, lodges and ecclesiastical groups seek to knit the loyalty of their followings to a flag or banner, a color or design. The State announces rank, function, and authority through crowns and maces, uniforms and black robes; the church speaks through the Cross, the Crucifix, the altar and shrine, and clerical raiment. Symbols of State often convey political ideas just as religious symbols come to convey theological ones. ${ }^{29}$

Children of grade-school age are intellectually undeveloped and particularly susceptible to the influence of their reachers. ${ }^{30}$ The student must be receptive and attentive to the words and actions of his teachers. This relationship must be considered in light of the fact that religion is an acquired belief ${ }^{31}$ and that the appeal of religion is primarily emotional..$^{32}$

The net effect of these influences is to give the garbed teacher's religion a prominent place in the student's mind; perhaps even to engender conflict with parental control over the child's religious training. ${ }^{33}$ Though such influence may fall short of sectarian "teaching," it provides the foundation and appetite for such teaching. The presence of representatives of a religion before the compulsory audience of the schoolroom gives the religion an unfair advantage. ${ }^{34}$ What the student hears and sees of a religiously garbed instructor is

319 U.S. 624 (1943). This case involved members of Jehovah's Witnesses who complained that a compulsory salute to the American flag was contrary to their religious beliefs. Though the case is not pertinent on its facts, it is an able exposition of the force of symbolism.

2 Ibid., at 632 .

${ }^{30}$ This factor was emphasized in Berghorn v. Reorganized School Dist. No. 8, - Mo. ,- 260 S.W. $2 d 573,578$ (1953).

s1 "The child's first religious beliefs are acquired. They are not inborn. He learns them from others. In fact, his earliest ideas, beliefs, etc., along all lines, religion included, come from his experiences and from what he is told. The young child is a believer; at first he believes everything he is told. . . . He believes what parent, teacher, minister, or priest tell him. His notions are crude replicas of their statements, modified to be sure, somewhat in accordance with his state of language development. He uncritically accepts all teachings because he bas not the experiential and developmental backgrounds necessary for their critical evaluation. His earliest religious beliefs rest upon unquestioned authority." Brooks, Psychology of Adolescence 337-38 (1929).

32 "As with children so with most adults the appeal of religion is first to the heart, and only secondarily to the head. The highest type of faith, said Aquinas, is fides formata per caritatem, faith given form by love." Grensted, The Psychology of Religion 106 (1952).

${ }^{33}$ Consult, generally, Friedman, The Parental Right To Control the Religious Education of a Child, 29 Harv. L. Rev. 485 (1916).

3t Zellers v. Huff, 55 N.M. 501, 236 P. $2 d 949$ (1951). 
credited not to the individual but to the religion into which the teacher's personality has been merged..$^{35}$

The reason for removing all sectarian influences from the public school is to prevent these institutions from becoming

the centers of local political battles which would be dangerous to the peace of society where there must be equal religious rights to all and special religious privileges to none. ${ }^{36}$

It must be admitted that complete separation of church and state is not practiced in the United States. For example, the government supports denominational chaplains in the armed services and G.I. benefits for training clerics. However, the exceptions exist only where separation would inhibit freedom of religion - the very rationale for separation. ${ }^{37}$ The garb issue presents no such interference with freedom of religion; the banning of religious garb in public schools does not hinder one's relationship with God.

Nor can the sectarian influence of garb be defended because a majority of the pupils in the public school may be of the same religion as the teacher. ${ }^{38}$ The acceptance of such an argument tends to obliterate the separation of church and state.

If numerical predominance of one sect in a given place is to be used as justifcation for the intrusion of its sectarian teachers and teachings into the public schools, then Roman Catholics, Protestants, Jews, and all others will suffer a deprivation of their rights in every community where they happen to be in a minority, each in turn. The application of the "majority-faith" approach can only result in the destruction of the public school system and its replacement by a series of competing systems of tax-supported denominational schools. ${ }^{39}$

It is difficult to draw a line denoting the point at which the intensity of the sectarian influence of the garb requires injunction. Further research on the psychological plane would be necessary to determine the precise effect of a teacher's religious habit. ${ }^{40}$ In any event, the influence is sufficient to justify statutory prohibition. Furthermore, the religious friction aroused in parents together with the sectarian influence on the children may justify prohibiting

\footnotetext{
${ }^{35}$ "A child receives instruction by seeing, as well as by hearing. The impressions made upon him by being exposed day in and day out to the sectarian atmosphere implicit in the daily routine, the physical surroundings and the habit of their order worn by the teachers, set forth in the court's findings may well prove as potent an influence in determining religious development as would a regularly prescribed course of instruction in formulated precepts." Brown, J., dissenting in City of New Haven v. Town of Torrington, 132 Conn. 194, 204, 43 A. 2d 455, 460 (1945).

${ }^{30}$ Harfst v. Hoegen, 349 Mo. 808, 817, 163 S.W. 2d 609, 614 (1942).

${ }^{87}$ Consult Katz, op. cit. supra note 10 , at $426-40$.

${ }^{38}$ E.g., see State ex rel. Johnson v. Boyd, 217 Ind. 348, 28 N.E. 2 d 256 (1940).

${ }^{39} 6$ Church and State, No. 7, at 4 (July, 1953).

${ }^{10}$ It is not wholly realistic to view the garb issue apart from the other associated influences typically found in the cases. See note 15, supra. However, garb is significant in that it does effuse a sectarian influence of its own.
} 
religious garb in the public schools even when no statute is present-particularly in view of the fact that the hardship on the religious may be negligible. ${ }^{41}$

"Modification of garb to fit necessity is recognized by the Catholic Church. Codex Juris Canonici, Canon 136, $\$ 1$ : "All clerics should wear a becoming ecclesiastical dress, according to the legitimate local customs and the prescriptions of the ordinary [bishop] of the place." Canon 596: "Religious must wear the proper habit of their own religious group both indoors and outdoors unless some grave cause excuses and this is to be decided by the superior."

\section{SHAREHOLDERS' LIABILITY FOR SALE OF CONTROLLING INTEREST}

The right of a controlling shareholder to dispose of his interest in a corporation is subject to few restrictions. Perlman v. Feldmann, ${ }^{1}$ recently decided by the Court of Appeals for the Second Circuit, raises the possibility that these restrictions may be greatly extended. This comment will examine that case to determine whether it departs significantly from prior law, or can be reconciled within the existing framework of cases.

\section{I}

For some time prior to 1950 steel had been in short supply, and producers were able to command a high price for their product. Industry ethics, however, frowned upon raising mill list prices, although this was not illegal, and it was customary for small producers to take advantage of the favorable market situation by indirectly raising their prices. Newport Steel Corporation sold its steel at the standard mill list price, but required that the purchaser make an interest-free advance of the purchase price long before delivery. ${ }^{2}$ The real price charged by Newport, therefore, consisted of the amount of the mill list price plus a "premium," the value of the use of the money advanced by the purchaser. The steel shortage was aggravated by the Korean War in $1950 .^{3}$

In August 1950, Feldmann, Newport's controlling shareholder, ${ }^{4}$ sold his

${ }^{2} 219$ F. 2 d 173 (C.A. 2d, 1955).

" "Between 1946 and 1947 Newport entered into separate contracts with seven large steel users by which, in consideration for commitments to deliver specified quantities of steel from its existing facilities, the customers "advanced" an aggregate of $\$ 3,510,000$ without interest, to be treated as $10 \%$ of the price of steel thereafter to be delivered over a 36-months' period." Brief for Appellant at 14, Perlman v. Feldmann, 219 F. 2d 173 (C.A. 2d, 1955). "During 1948-1949 Newport raised $\$ 10,000,000$ from customers to buy additional facilities. ..." Ibid.

${ }^{3}$ Certain sellers were able to obtain up to $100 \%$ or more above the mill list prices. Wall Street Journal, p. 3 , col. 3 (July 27,1950 ).

-Thirty-seven per cent of the shares constituted control in this instance. The controlling shares were owned by Feldmann and members of his family. Those members were joined with Feldmann as defendants in the suit and the judgment finally rendered was directed against them as well as Feldmann. However, because Feldmann took the 